\title{
Required Professional Competences of Special Education Teachers at Prep Schools
}

\author{
Prof Uaifa Al-Dalabih ${ }^{1}$, Fahd Al-Azmy ${ }^{2}$ \\ ${ }^{1}$ General Curriculum, College of Educational Sciences, Al Al-Bayt University \\ ${ }^{2}$ MSc. Methodology Al Al-Bayt Universities, Faculty of Educational Sciences
}

\begin{abstract}
The current study tries to explore the professional competences required for making special education teachers successful in dealing with different kinds of disabilities and able to be emerged with usual schools. Also, the study aims at finding good teachers of special education. The research sample included 25 teachers of special education. A 20 - clause questionnaire was designed to discover the required competences for teachers' success in special education. The results demonstrated differences with statistical significance in the professional competences of special education teachers. Results were collected according to teachers' views.
\end{abstract}

Keywords: Professional competences, special education teachers, children with special needs

\section{Introduction}

At the age of knowledge economy, it is a must to make a teacher's role and competence up to date since a teacher is the friend, leader, inventor and guide for learning ( $\mathrm{Al}-$ Hajrasi,2003). Thus, a teacher should be knowledgeable and own a critical and self-view. Competences of teacher include high academic skills, emotional qualities, and skills of challenge and excellence besides ability of justice leadership of a class (Merhi, 1983). Moreover, giving due care with expanding in merging handicapped students with usual schools forced us to have special education teachers with new personal qualities regarding their rehabilitation programs (To'eima, 2006) . Instead of directing money and services for isolated centers of disabled people, it is a must to make special education teachers ready to work with their peers from usual schools. So, those teachers should have communication and cooperation with teachers in usual schools (Debis, 1993). In addition, teachers of special education should have enough knowledge about educational system of usual schools and have the ability to achieve goals and taking care of individual differences for their students besides using modern teaching ways (Al-AbdulJabbar,1998).Also, they should make activities and depend on comprehensive evaluation for skillful and emotional aspects for students (Mansour, 2002).

\section{Methodology}

The current study aims at analyzing the role of special education teachers who are considered the cornerstone of educating children with special needs. That type of teachers became sought - after one since they do their best in dealing with disabled persons which their numbers increase day after day. Thus the research clarifies the required qualifications and competence of those teachers. The 25 teachers of the study sample are asked to give answers for 4 kinds of competences: cognitive competence, employing technology competence, teaching competence and class management. The researcher used SPSS program to calculate arithmetic mean and standard deviations to get the relative measure of each skill besides using " $\mathrm{T}$ " test to explore the important competences between teachers in usual schools and teachers of special education.

\section{Results}

After applying( 40)clause questionnaire on a sample of (25) teachers at special education schools in the year 
(2018/2019) , main and subsidiary competences were arranged regarding their importance as the next Table(1) shows :-

Table (1) important competences starting from teaching competence, then cognitive, class management and finally employing technology competences.

\begin{tabular}{|l|c|c|c|}
\hline \multicolumn{1}{|c|}{ Competences } & Means & Deviation & $\begin{array}{c}\text { deviation } \\
\text { square }\end{array}$ \\
\hline Cognitive Competences & 31.56 & 6.641 & 44.143 \\
\hline $\begin{array}{l}\text { Employing Technology } \\
\text { Competences }\end{array}$ & 15.44 & 9.476 & 89.795 \\
\hline Teaching Competences & 33.23 & 8.314 & 69.12 \\
\hline $\begin{array}{l}\text { Class Management } \\
\text { Competences }\end{array}$ & 20.93 & 3.986 & 15.8 \\
\hline
\end{tabular}

\section{Discussion}

The previous results showed that the most important competences of special education teachers are related to teachers needs to support their vocational aspects. These results agree with other studies in that field which confirms the importance of teacher's possession to vocational and personal competences to make him successful. Also, the previous table shows that it is important for teachers of special education to acquire competences such as knowing learning theories, evaluation, planning and communication with children and parents to make teaching effective.

\section{Recommendations}

1- It is important to care with choosing special education teachers who have the required qualities for their jobs.

2- Developing the professional and training competences of teachers to upgrade their level of working with disabled children.

3- Responsible organizations of special education should provide (Non- Qualified) teachers with programs and training courses to serve the opportunity for them to gain the required skills and competences.

4- Teachers should cooperate with parents to guide them to how they deal with their children

\section{Conclusion}

The process of developing the personal and vocational aspect for special education teachers becomes an urgent necessity for supporting methodological performance. Thus, it is a must to prepare training programs for teachers to develop their competence.

\section{References}

[1] Al-Hajrasi , Moawad, (2003), Raising mentally handicapped children, Dar Al-Fikr Al-Arabi, Cairo.

[2] Merhi ,Tawfiq: (1983) AD, educational competencies in the light of systems, 1st floor, Dar Al-Furqan for Publishing and Distribution, Jordan.

[3] To'eima ,Rushdi (2006): The teacher: his competencies, preparation, and training. Cairo: Dar Al-Fikr Al-Arabi.

[4] Debis ,Saeed (1993): Skills for Deaf Teachers in the City of Riyadh - An Exploratory Study, Journal of Arts and Humanities, Volume XI, First Issue, pp. 1--29.

[5] Debis ,Saeed (1994): Occupational pressures among special education teachers and their relationship to the point of control: Journal of Contemporary Psychology, Special Issues Series, pp. 150.

[6] Al-Abdul-Jabbar, Abdulaziz (1998): Study the competencies necessary for the teacher of hearing impaired children - the importance of their availability. Journal of the Faculty of Education, Ain Shams University, M3, 47-86.

[7] Mansour ,Abdullah: (2002), the role of the educational supervisor in developing the educational competencies necessary for teachers of social subjects, Master Thesis, College of Education, King Saud University, Riyadh 